\title{
REVIEW
}

\section{Psoriatic arthritis: recent progress in pathophysiology and drug development}

\author{
Douglas James Veale $e^{1,2}$
}

\begin{abstract}
Psoriatic arthritis (PSA) is the second most common inflammatory arthropathy, after rheumatoid arthritis diagnosis, in early arthritis clinics. Most patients have established psoriasis, often for years, prior to the onset of joint pain and swelling; in addition, associated features of nail disease, dactylitis, enthesitis, spondylitis or uveitis may be present. Psoriasis may not be immediately apparent, as small or patchy lesions may occur in the scalp or perineum. PsA presents as a symmetrical polyarthritis, similar to rheumatoid arthritis, or an asymmetrical oligoarthritis with a predilection for the distal interphalangeal joints. Spinal involvement is similar, although not identical, to ankylosing spondylitis. Joint damage occurs early; up to $50 \%$ of PsA patients have an $11 \%$ annual erosion rate in the first 2 years of disease duration, suggesting it is not a benign condition. There have been significant advances in our understanding of PSA pathogenesis in recent years, in the areas of genetics and molecular biology, implicating both the innate and the adaptive immune systems. This has lead to the introduction of evidence-based targeted therapy, primarily with tumour necrosis factor inhibitor (TNFi) agents. Therapy with disease-modifying anti-rheumatic drugs, such as methotrexate and leflunomide, remains the first-choice therapeutic intervention, even though there are few randomised controlled trials with these agents. In contrast, a number of successful studies of TNFi agents demonstrate excellent efficacy, in combination with methotrexate, and several novel agents are currently in development for the treatment of PsA.
\end{abstract}

\section{Introduction}

Psoriasis $(\mathrm{PsO})$ is a common dermatosis characterised by thickened, red and scaly plaques [1]. PsO affects up to $2 \%$ of the population, often presenting in adolescence, on the scalp, and the extensor surfaces of the elbows and knees, although covert lesions may occur in the natal cleft, the navel or in the perineum. Psoriatic arthritis (PsA) develops in 10 to $40 \%$ of $\mathrm{PsO}$ patients depending on the source of the study population, as in an academic teaching hospital or in the community. In $80 \%$ of patients the arthritis manifests after the development of PsO, often by 10 years or more [2].

PsA may appear in a very similar clinical pattern to rheumatoid arthritis (RA), as a symmetrical small joint arthropathy involving the wrists, metacarpophalangeal joints and the proximal interphalangeal joints. In contrast, patients may develop asymmetric joint involvement, including

\footnotetext{
Correspondence: douglas.veale@ucd.ie

${ }^{1}$ Dublin Academic Medical Centre, Centre for Arthritis and Rheumatic Diseases, St Vincent's University Hospital, Elm Park, Dublin 4, Ireland

${ }^{2}$ The Conway Institute of Biomolecular and Biomedical Research, University College Dublin, Dublin 4, Ireland
}

a characteristic inflammatory arthritis of the distal interphalangeal joints, often colocalised with trophic changes in the associated nail. Patients are now defined as negative for circulating rheumatoid factor. In addition to PsO, PsA has a number of long-recognised associated clinical features including dactylitis, enthesitis, spondylitis and uveitis, the latter three resulting in grouping of PsA in the classification of seronegative spondyloarthropathies. The nail dystrophy includes features such as pitting and onycholysis that are present in up to $60 \%$ of patients with $\mathrm{PsO}$, and equally may affect the fingernails and the toenails [3]. The association of the nail dystrophy with arthritis at the distal interphalangeal joint has recently led to the proposal of a common pathophysiologic mechanism [4]. A polyarticular or oligoarticular peripheral arthritis will account for $75 \%$ of new cases of PsA, but patients may present with a pure spondylitis on a clinical background of $\mathrm{PsO}$ [2].

Many different clinical classifications have been proposed for PsA since the original subtypes were described in 1973; however, the most recent was developed by an international multicentre study resulting in the CASPAR criteria and has now been widely adopted [5]. Five hundred 
and eighty-eight PsA patients were compared with 536 consecutive controls in a prospective clinical study examining these diagnostic criteria in relation to existing classification criteria in defining PsA. The CASPAR criteria have $98 \%$ specificity and $91 \%$ sensitivity.

There are reports suggesting that PsA is a benign arthropathy and erosive bone damage is uncommon [6], but Kane and Pathare examined an early arthritis clinic cohort followed up over 2 years and reported significant bone erosions in as many as $50 \%$ of PsA patients despite apparently good disease control with disease-modifying anti-rheumatic drugs such as methotrexate [7]. The primary objective in the management of PsA is to relieve signs and symptoms of the arthritis, but increasingly treatment strategies also aim to preserve function, prevent disability and maintain quality of life. These therapeutic strategies have targeted both the skin and joint features of disease, and more recently have set out to prove efficacy in the associated features of nail dystrophy, dactylitis, enthesitis, uveitis and spondylitis. As in the management strategies for RA, early diagnosis and introduction of effective treatment is pivotal to control inflammation, and prevent damage and disability. Over the last 12 years the use of targeted biologic therapies, namely tumour necrosis factor inhibitor (TNFi) agents, has revolutionised the therapy of both $\mathrm{PsO}$ and PsA, such that the combination therapy of methotrexate plus a TNFi is a widely used therapeutic intervention in PsA [8]. The spectrum of targeted therapies using specific biologic agents to block the inflammatory cascade has further been expanded to include IL-17 and IL-12/23. In addition, there is evidence to support using the CD80/86 receptor costimulatory molecule abatacept to treat PsA [9]. More recently, several small molecular inhibitors are in development and will undoubtedly be developed for the treatment of $\mathrm{PsO}$ and PsA.

\section{Pathophysiology of psoriatic arthritis}

In $\mathrm{PsO}$ and PsA, as in many autoimmune and autoinflammatory diseases, there is a complex interaction of genetic and environmental factors leading to a selfsustained and persistent immune response. What is not clear, however, is the relationship between skin disease and joint disease, because it now appears they may have independent rather than shared genetic associations. In addition, the evidence for environmental influences is limited due to the heterogeneous clinical phenotypes. As a result, the debate continues in relation to $\mathrm{PsO}$ and PsA being different manifestations of the same disease [10].

The broad clinical spectrum in PsA disease probably reflects a significant genetic heterogeneity, evident from the results of the numerous early human leukocyte antigen (HLA) association studies [11,12]. The more recent genome-wide association studies provide further evidence of genetic heterogeneity; although modest in size, they do suggest links between key factors in the immune responses both locally in the skin and also systemically, implicating both innate and adaptive immunity [13,14]. Genes identified in relation to specific networks of signalling molecules implicated in the barrier function of skin include LCE3, DEFB4, and GJB2, while TNFAIP3, TNIP1, NFKBIA, REL, FBXL19, TYK2, and NOS2 involved in nuclear factor- $\mathrm{kB}$ and interferon signalling are implicated in the innate immune system, and $H L A-C, I L-12 B$, $I L-23 R, I L-23 A, T R A F 3 I P 2$, and ERAP1 relate to CD8 T-lymphocyte and IL-23/IL-17-mediated lymphocyte signalling in the adaptive immune response [13-15]. In another recent report, the RUNX3 gene has been reported to be overexpressed in patients with PsO and PsA. RUNX3 is an important transcriptional regulator of CD8 T-cell differentiation, so this observation provides further evidence for the potential role of CD8 T-cell-dependent pathways in PsA [16].

In a review of the genome-wide association study data, Bluett and Barton highlight that, of all the genetic associations, many are in fact shared between PsO and PsA, except for HLA B27 and the IL-13 gene locus [17]. In addition to the HLA B27 link between PsA and ankylosing spondylitis, a number of other shared genetic associations have been confirmed including those implicated in lymphocyte signalling, notably ERAP1, IL-23R and IL12B [18]. An interesting functional link has been described in an animal model of enthesitis, in which a unique IL$23 \mathrm{R}^{+}$, RAR-related orphan receptor $\mathrm{\gamma t}^{+} \mathrm{CD}^{+} \mathrm{CD}^{-} \mathrm{CD}^{-}$, stem cell antigen $1^{+}$T-cell subset is resident at the entheseal insertion [19]. This is evidence that IL-23 is essential for the development of enthesitis by acting on this unique resident $\mathrm{T}$-cell subset. The importance of these observations in novel drug development is clear because the IL17/IL-23 axis is now being targeted with new monoclonal antibody therapies in $\mathrm{PsO}$ and is under investigation (phase II studies) for the treatment of PsA. The association with HLA B27 and CD8 T-lymphocyte function also supports a potential pathogenic role as the major histocompatibility complex class I molecules may present arthritogenic peptides to $\mathrm{CD} 8^{+} \mathrm{T}$ lymphocytes or select an autoreactive T-cell repertoire.

There is some evidence that trauma or infection may be a potentially important environmental trigger in genetically susceptible individuals for both $\mathrm{PsO}$ and PsA. One early study did report an association between trauma and the later development of PsA in a digit, which was known as the deep Koebner response after the well-described Koebner response phenomenon in $\mathrm{PsO}$ [1]. Although the mechanism of the Koebner phenomenon is poorly understood, stimulation of sensory nerve endings and release of proinflammatory neuropeptides, as a result of trauma, probably trigger an immune response [20]. Neuropeptides, 
including substance $\mathrm{P}$ and vasoactive intestinal peptide, are reported as overexpressed in lesional skin of PsO patients and in synovial tissue of PsA [21,22]. A role for psychological stress has also been proposed, although it is difficult to elucidate a mechanistic pathway for stress - it may also be linked to neuropeptide release within the central nervous system. A small number of studies and case reports provide some evidence of a temporal link between physical trauma and the onset of PsA [23,24].

A close relationship has been reported between streptococcal infections and the onset of a subset of skin disease, guttate $\mathrm{PsO}$, which appears to be linked to the HLA-Cw*06 genotype [25]. The presence of bacteria or related antigens, however, has not been described in the synovial tissue from joints of PsA patients. HIV has also been associated with an increased incidence of developing $\mathrm{PsO}$ and PsA, which raises the possibility that specific $\mathrm{CD} 8^{+} \mathrm{T}$ cells play a pathophysiological role in the skin and joint disease [26].

Innate and adaptive immunity appears to be dysregulated in patients with PsO and PsA. As mentioned above, the recent genome-wide association studies provide evidence that nuclear factor- $\mathrm{k} B$ and interferon signalling, key regulators in the innate immune system, are associated with both PsO and PsA. In addition, there is evidence that genes associated with the adaptive immune response, in particular T-helper type (Th)1 and Th17 cells, are also associated with these diseases. In PsO skin lesions, the genomic data implicate $\mathrm{T}$ cells but also dendritic cells as key in the inflammatory process, while interferon-gamma and tumour necrosis factor (TNF) $\alpha$ appear to be the key cytokines. In early $\mathrm{PsO}$ skin lesions, the plasmacytoid dendritic cells appear to be increased in number - these may be activated in a Toll-like receptor-9-dependent mechanism by trauma, as suggested above, or infection, for example antimicrobial peptide LL-37 cathelicidin [27]. In PsO skin the plasmacytoid dendritic cell has an important inducer role by release of interferon-alpha [1]. At the same time, keratinocytes in the expanded $\mathrm{PsO}$ epidermis are a rich source of proinflammatory trigger molecules including antimicrobial peptides such as LL-37, $\beta$ defensins and S100A7 (psoriasin) that appear to be regulated by IL-23 [28]. Th1 differentiation appears to be dependent in particular on IL-12, the main source of which is the dendritic cells. Th1 cells secrete mainly interferon-gamma, TNFo and IL-1, but the importance of IL-17, produced mainly by Th17 cells but also possibly by neutrophils and mast cells, has increasingly been recognised in the past few years [29]. The Th17 cell may be especially important in the immune responses and barrier function of the skin, because it also secretes IL-22, a key cytokine driving adaptive immune cell function and keratinocyte proliferation. The production of IL-17 by Th17 cells appears to be largely under the influence of IL-21, a mechanism that involves activation of the signal transducer and activator of transcription
(STAT) signalling pathway [30], and is an important observation in relation to kinase inhibitors that may soon be available for the treatment of $\mathrm{PsO}$ and PsA.

Braverman and Yen described morphological vascular changes in PsO skin in the early 1970s [31]. The subsequent revelation that $\mathrm{T}$ cells undergo clonal expansion only after they migrate across the vascular endothelium suggests a key primary role for these cells in the evolution of the inflammatory lesion in PsO and PsA.

Many angiogenic cytokines including TNF, transforming growth factor beta, platelet-derived growth factor, and vascular endothelial growth factor are overexpressed in $\mathrm{PsO}$ skin and may be responsible for inducing changes in effector cell function as well as in endothelial cell function and growth. Similar morphological changes have been described in the synovial blood vessels in the PsA joint, and recently we have described associations with significant functional changes in infiltrating immune cells at a molecular level [32]. This further suggests that vascular endothelial cells participate actively in the immune response rather than act as a passive conduit for lymphocytes and monocytes entering inflamed tissues. Indeed, there is a close link between angiogenesis, inflammation, tissue hypoxia and the production of cytokines and matrixdegrading enzymes such as the metalloproteinases that facilitate effector cell activation and migration in the synovial tissue in vivo [33].

The chronic inflammatory lesion in $\mathrm{PsO}$ and in PsA appears fundamentally reliant on the presence of a brisk and persistent vascular response, which in turn is directly related to joint damage and possibly bone erosion. Many of the destructive matrix metalloproteinase enzymes are upregulated in the synovium, usually in response to cytokines (for example, IL-1 and TNFa). Bone erosion and severe osteolysis in a subgroup of PsA patients has led to a focus on the role of the osteoclast. Increased osteoclast activity at the cartilage-pannus junction also appears to be associated with increased receptor activator of nuclear factor- $\kappa \mathrm{B}$ ligand expression and reduced osteoprotegerin. In a recent report, we have shown that the receptor activator of nuclear factor- $\mathrm{kB}$ ligand/osteoprotegerin can be altered via histamine acting through an orphan receptor in human chondrocytes. [34]. Osteoclast precursor cells have recently been described circulating in increased numbers in peripheral blood of PsA patients but may be suppressed following treatment with TNFi agents [35].

\section{Drug development for psoriatic arthritis}

The aim of treatment for PsA patients is to provide symptom relief, to prevent disability, to maintain function and to improve quality of life. In this respect, the introduction of biologic agents - mostly in combination with conventional disease-modifying anti-rheumatic drugs methotrexate, leflunomide, and salazopyrine - has 
revolutionised PsA therapy. In particular, the TNFi drugs appear to effectively inhibit the inflammatory response, while also preventing bone erosion, thereby preserving function and quality of life. New targeted biologic therapies have recently been reported as effective, including anti-cytokine drugs against TNF $\alpha$, IL-17 and IL-12/23, while the co-stimulatory molecule CTLA4Ig has also been shown to be effective in PsA. Small molecule inhibitors targeting kinases, which are delivered per oral, may be developed for the treatment of PsO and PsA.

\section{Tumour necrosis factor inhibitor therapy for psoriatic arthritis}

TNF targeted therapy appears to be highly effective for the symptoms and signs of peripheral joint arthritis; however, in contrast to conventional disease-modifying anti-rheumatic drug agents, TNFi drugs also appear highly effective in treating spinal symptoms [8]. There are now five TNFi agents available, all showing apparently equivalent efficacy in the skin and joint manifestations of PsO and PsA [36,37]. TNFi agents are costeffective and inhibit radiological progression of bone erosions in peripheral joints, maintain function and improve quality of life [38]. The results from the British Society for Rheumatology Biologics Register observational cohort study highlight the effectiveness of TNFi therapy in the treatment of patients with PsA [39]. The more recently developed TNFi agents golimumab and certolizumab pegol have also been shown effective in the treatment of PsA [40,41]. Golimumab is a nextgeneration TNF-targeting monoclonal antibody with high affinity, greater TNF-binding capacity and therefore a dosing interval extended to once a month - the reduced frequency of self-injection may be attractive to patients. Certolizumab pegol is a polyethylene glycolylated Fab' fragment of a humanised monoclonal antibody, the polyethylene glycol moiety markedly increasing the halflife of the drug. In contrast to other TNFi agents, certolizumab pegol did not mediate increased levels of apoptosis, suggesting that these mechanisms are not essential for the TNFi effect [42].

\section{Novel biologic therapies for psoriatic arthritis}

In recent years, a number of biologic agents have been developed against candidate targets identified by studies of the pathophysiology of PsA. T-cell receptor activation follows interaction and binding of the T-cell surfaceexpressed CD28 molecule with the CD80/86 molecule on the surface of the antigen-presenting cell, producing a second costimulatory signal. Abatacept is a soluble, fully human fusion protein consisting of the extracellular domain of CTLA-4 linked to a modified Fc portion of human IgG1. Expression of CTLA-4 after activation competes with CD28 binding to CD80/86, which in turn leads to homeostatic downmodulation of activated T cells. Abatacept therefore selectively inhibits T-cell activation via competitive binding to CD80/86 and subsequent reduction in the levels of proinflammatory cytokines [43]. At higher doses, abatacept has been shown effective in the treatment of a significant subgroup of PsA patients [9].

Probably the most significant advances in our understanding of the pathophysiology of PsO and PsA, as outlined above, are around the IL-17 and IL-12/IL-23 pathway and the characterisation of the Th17 cell. Several monoclonal antibodies have been developed and shown to be effective in targeting this key regulatory pathway in patients with PsO and/or PsA. A first study shows the effects of secukinumab, a fully human anti-IL-17A monoclonal antibody, in a small proof-of-concept study; the second demonstrates efficacy of a fully human anti-IL-12/IL-23 monoclonal antibody, ustekinumab, in a large, phase III randomised controlled trial $[44,45]$. The secukinumab study included 42 patients for 24 weeks and failed to meet the primary endpoint; however, significant improvements in secondary measures were observed. Ustekinumab, recently approved for use in PsA by the US Food and Drug Administration, was studied in over 600 active PsA patients and showed significant responses compared with placebo over 52 weeks and may offer an alternative therapeutic mechanism of action to currently approved biological treatments. Finally, the two anti-IL-17 receptor antibodies brodalimumab and ixekizumab have been shown in short phase II studies to be significantly beneficial in plaque PsO, but studies in PsA are awaited [46,47].

\section{Small molecule inhibitors for psoriatic arthritis}

Biologic therapies have offered a major advance in the treatment of PsA over the past decade. In our experience, a remission rate of $60 \%$ may be achieved in routine clinical practice, but some patients demonstrate an inadequate or poor response [48].

The most recent advances in drug development have focused on small molecule inhibitors, including the phosphodiesterase 4 inhibitor apremilast, in PsO, PsA and RA, and the kinase inhibitors in RA and PsO. Some long-term results of a large phase III randomised controlled trial (PALACE 1 study) of apremilast in PsA were presented at the recent European League Against Rheumatism meeting [49]. Over $60 \%$ of patients receiving $20 \mathrm{mg}$ twice daily and completing 52 weeks of the study demonstrated an American College of Rheumatology $20 \%$ improvement response. There were no new safety concerns, although tolerability due to gastrointestinal disturbances can be an issue in the short term. There are a number of kinase inhibitors targeting Jak $1 / 2$, Jak3, and Syk in development, and tofacitinib targeting primarily Jak3 is now licensed for use in RA patients in the USA, Japan and Switzerland. Tofacitinib has been the 
subject of detailed and extensive clinical trials in RA patients, demonstrating significant benefit for the signs and symptoms of RA, and inhibits radiological progression [50]. Furthermore, a phase IIb study of tofacitinib has shown significant improvement in moderate-tosevere $\mathrm{PsO}$ [51]. There are clinical trials ongoing with tofacitinib in patients with $\mathrm{PsO}$ and/or PsA; in addition, trials are registered at clinicaltrials.gov, but have not yet commenced, of tofacitinib in patients with PsA.

\section{Conclusion}

There have been significant advances in the detailed genetic and immunologic factors implicated in the pathophysiology of PsA in recent years. Many of these advances have been informed by rapid improvement in technologies, with respect to genomics and molecular biology, and by our increased knowledge of the immunology of inflammatory autoimmune diseases including $\mathrm{RA}$ and $\mathrm{PsO}$. The exciting progress of drug development outlined in this article is, in part, directly related to the translational research and implementation of knowledge gained and to advanced technology in the past two decades. The challenges for clinicians and rheumatologists remain complex: how can patients be identified at the earliest timepoint; can we develop useful new biomarkers for early diagnosis and prognosis; and, finally, can we personalise the growing number of therapeutic interventions to individuals or groups of patients?

\section{Abbreviations \\ HLA: Human leukocyte antigen; IL: Interleukin; PsA: Psoriatic arthritis; PsO: Psoriasis; RA: Rheumatoid arthritis; Th: T-helper type; TNF: Tumour necrosis factor; TNFi: Tumour necrosis factor inhibitor.}

\section{Competing interests}

DJV received unrestricted educational funding from Abbvie, Actelion, MSD, Opsona, Pfizer, Roche and UCB; is on the speaker bureau for Actelion, MSD, Pfizer, Janssen, and UCB; and is advisor to Abbvie, Actelion, MSD, Pfizer, Roche and UCB.

\section{Published: 18 Dec 2013}

\section{References}

1. Nestle FO, Kaplan DH, Barker J: Psoriasis. N Engl J Med 2009, 361:496-509.

2. Veale $D$, Rogers $S$, Fitzgerald $O$ : Classification of clinical subsets in psoriatic arthritis. Br J Rheumatol 1994, 33:133-138.

3. Klaassen KM, van de Kerkhof PC, Pasch MC: Nail psoriasis: a questionnairebased survey. Br J Dermatol 2013, 169:314-319.

4. McGonagle DG, Helliwell P, Veale D: Enthesitis in psoriatic disease. Dermatology 2012, 225:100-109.

5. Taylor W, Gladman D, Helliwell P, Marchesoni A, Mease P, Mielants H, CASPAR Study Group: Classification criteria for psoriatic arthritis: development of new criteria from a large international study. Arthritis Rheum 2006, 54:2665-2673.

6. Shbeeb M, Uramoto KM, Gibson LE, O'Fallon WM, Gabriel SE: The epidemiology of psoriatic arthritis in Olmsted County, Minnesota, USA, 1982-1991. J Rheumatol 2000, 27:1247-1250.

7. Kane D, Pathare S: Early psoriatic arthritis. Rheum Dis Clin North Am 2005, 31:641-657.

8. Gossec L, Smolen JS, Gaujoux-Viala C, Ash Z, Marzo-Ortega H, van der Heijde D, FitzGerald O, Aletaha D, Balint P, Boumpas D, Braun J, Breedveld FC,
Burmester G, Canete JD, de Wit M, Dagfinrud H, de Vlam K, Dougados M, Helliwell P, Kavanaugh A, Kvien TK, Landewe R, Luger T, Maccarone M, McGonagle D, McHugh N, McInnes IB, Ritchlin C, Sieper J, Tak PP, et al: European League Against Rheumatism recommendations for the management of psoriatic arthritis with pharmacological therapies. Ann Rheum Dis 2012, 71:4-12.

9. Mease P, Genovese MC, Gladstein G, Kivitz AJ, Ritchlin C, Tak PP, Wollenhaupt J, Bahary O, Becker JC, Kelly S, Sigal L, Teng J, Gladman D: Abatacept in the treatment of patients with psoriatic arthritis: results of a six-month, multicenter, randomized, double-blind, placebo-controlled, phase II trial. Arthritis Rheum 2011, 63:939-948.

10. Ciocon DH, Kimball AB: PsO and psoriatic arthritis: separate or one and the same? Br J Dermatol 2007, 157:850-860.

11. Lambert JR, Wright V, Rajah SM, Moll JM: Histocompatibility antigens in psoriatic arthritis. Ann Rheum Dis 1976, 35:526-530.

12. Gladman DD, Anhorn KA, Schachter RK, Mervart H: HLA antigens in psoriatic arthritis. J Rheumatol 1986, 13:586-592.

13. Apel M, Uebe S, Bowes J, Giardina E, Korendowych E, Juneblad K, Pasutto F, Ekici AB, McManus R, Ho P, Bruce IN, Ryan AW, Behrens F, Böhm B, Traupe H, Lohmann J, Gieger C, Wichmann HE, Padyukov L, Fitzgerald O, Alenius GM, McHugh NJ, Novelli G, Burkhardt H, Barton A, Reis A, Hüffmeier U: Variants in RUNX3 contribute to susceptibility to psoriatic arthritis, exhibiting further common ground with ankylosing spondylitis. Arthritis Rheum 2013, 65:1224-1231.

14. Hüffmeier U, Uebe S, Ekici AB, Bowes J, Giardina E, Korendowych E, Juneblad K, Apel M, McManus R, Ho P, Bruce IN, Ryan AW, Behrens F, Lascorz J, Böhm B, Traupe H, Lohmann J, Gieger C, Wichmann HE, Herold C, Steffens M, Klareskog L, Wienker TF, Fitzgerald O, Alenius GM, McHugh NJ, Novelli G, Burkhardt H, Barton A, Reis A: Common variants at TRAF3IP2 are associated with susceptibility to psoriatic arthritis and PsO. Nat Genet 2010, 42:996-999.

15. Ellinghaus E, Stuart PE, Ellinghaus D, Nair RP, Debrus S, Raelson JV, Belouchi M, Tejasvi T, Li Y, Tsoi LC, Onken AT, Esko T, Metspalu A, Rahman P, Gladman DD, Bowcock AM, Helms C, Krueger GG, Koks S, Kingo K, Gieger C, Wichmann HE, Mrowietz U, Weidinger S, Schreiber S, Abecasis GR, Elder JT, Weichenthal M, Franke A: Genome-wide meta-analysis of psoriatic arthritis identifies susceptibility locus at REL. J Invest Dermatol 2012, 132:1133-1140.

16. Nair RP, Duffin KC, Helms C, Ding J, Stuart PE, Goldgar D, Gudjonsson JE, Li Y, Tejasvi T, Feng BJ, Ruether A, Schreiber S, Weichenthal M, Gladman D, Rahman P, Schrodi SJ, Prahalad S, Guthery SL, Fischer J, Liao W, Kwok PY, Menter A, Lathrop GM, Wise CA, Begovich AB, Voorhees JJ, Elder JT, Krueger GG, Bowcock AM, Abecasis GR: Collaborative Association Study of PsO. Genome-wide scan reveals association of PsO with IL-23 and NF-KB pathways. Nat Genet 2009, 41:199-204.

17. Bluett J, Barton A: What have genome-wide studies told us about psoriatic arthritis? Curr Rheumatol Rep 2012, 14:364-368.

18. Jadon D, Tillett W, Wallis D, Cavill C, Bowes J, Waldron N, Dixon A, Sengupta R, Barton A, Korendowych E, McHugh NJ: Exploring ankylosing spondylitisassociated ERAP1, IL23R and IL12B gene polymorphisms in subphenotypes of psoriatic arthritis. Rheumatology (Oxford) 2013, 52:261-266.

19. Sherlock JP, Joyce-Shaikh B, Turner SP, Chao CC, Sathe M, Grein J, Gorman DM, Bowman EP, McClanahan TK, Yearley JH, Eberl G, Buckley CD, Kastelein RA, Pierce RH, Laface DM, Cua DJ: IL-23 induces spondyloarthropathy by acting on ROR- $\mathrm{t}^{+} \mathrm{CD} 3^{+} \mathrm{CD} 4^{-} \mathrm{CD} 8^{-}$entheseal resident T cells. Nat Med 2012, 18:1069-1076.

20. Fearon U, Veale DJ: Pathogenesis of psoriatic arthritis. Clin Exp Dermatol 2001, 26:333-337.

21. Eedy DJ, Johnston CF, Shaw C, Buchanan KD: Neuropeptides in PsO: an immunohistochemical and radioimmunoassay study. J Invest Dermatol 1991, 96:434-438.

22. Veale D, Farrell M, FitzGerald O: Mechanisms of joint sparing in a patient with unilateral psoriatic arthritis and a long-standing hemiplegia. Br J Rheumatol 1993, 32:413-416.

23. Punzi L, Pianon M, Bertazzolo N, Fagiolo U, Rizzi E, Rossini P, Todesco S: Clinical, laboratory and immunogenetic aspects of post-traumatic psoriatic arthritis: a study of 25 patients. Clin Exp Rheumatol 1998, 16:277-281.

24. Langevitz P, Baskila D, Gladman DD: Arthritis precipitated by physical trauma. J Rheumatol 1990, 17:695-697.

25. Mallbris L, Wolk K, Sánchez F, Ståhle M: HLA-CW*06 associates with a twofold higher prevalence of positive streptococcal throat swab at the onset of PsO: a case control study. BMC Dermatol 2009, 9:5. 
26. Espinoza LR, Berman A, Vasey FB, Cahalin C, Nelson R, Germain EF: Psoriatic arthritis and acquired immuno-deficiency syndrome. Arthritis Rheum 1988, 31:1034-1040

27. Reinholz M, Ruzicka T, Schauber J: Cathelicidin LL-37: an antimicrobial peptide with a role in inflammatory skin disease. Ann Dermatol 2012, 24:126-135.

28. Nakajima K, Kanda T, Takaishi M, Shiga T, Miyoshi K, Nakajima H, Kamijima R, Tarutani M, Benson JM, Elloso MM, Gutshall LL, Naso MF, Iwakura Y, DiGiovanni J, Sano S: Distinct roles of IL-23 and IL-17 in the development of PsO-like lesions in a mouse model. J Immunol 2011, 186:4481-4489.

29. Moran EM, Heydrich R, Ng CT, Saber TP, McCormick J, Sieper J, Appel H, Fearon U, Veale DJ: IL-17A expression is localised to both mononuclear and polymorphonuclear synovial cell infiltrates. PLoS One 2011, 6:e24048.

30. Wei L, Laurence A, Elias KM, O'Shea JJ: IL-21 is produced by Th17 cells and drives IL-17 production in a STAT3-dependent manner. J Biol Chem 2007, 282:34605-34610.

31. Braverman IM, Yen A: Microcirculation in psoriatic skin. J Invest Dermatol 1974, 62:493-502.

32. Gao W, Sweeney C, Walsh C, Rooney P, McCormick J, Veale DJ, Fearon U: Notch signalling pathways mediate synovial angiogenesis in response to vascular endothelial growth factor and angiopoietin 2. Ann Rheum Dis 2013, 72:1080-1088.

33. $\mathrm{Ng} \mathrm{CT}$, Biniecka M, Kennedy A, McCormick J, Fitzgerald O, Bresnihan B, Buggy D, Taylor CT, O'Sullivan J, Fearon U, Veale DJ: Synovial tissue hypoxia and inflammation in vivo. Ann Rheum Dis 2010, 69:1389-1395.

34. Marzaioli V, McMorrow JP, Angerer H, Gilmore A, Crean D, Zocco D, Rooney P, Veale D, Fearon U, Gogarty M, McEvoy AN, Stradner MH, Murphy EP: Histamine contributes to increased RANKL to osteoprotegerin ratio through altered nuclear receptor $4 \mathrm{~A}$ activity in human chondrocytes. Arthritis Rheum 2012, 64:3290-3301.

35. Anandarajah AP, Schwarz EM, Totterman S, Monu J, Feng CY, Shao T, Haas-Smith SA, Ritchlin CT: The effect of etanercept on osteoclast precursor frequency and enhancing bone marrow oedema in patients with psoriatic arthritis. Ann Rheum Dis 2008, 67:296-301.

36. Ritchlin CT, Kavanaugh A, Gladman DD, Mease PJ, Helliwell P, Boehncke WH, de Vlam K, Fiorentino D, Fitzgerald O, Gottlieb AB, McHugh NJ, Nash P. Qureshi AA, Soriano ER, Taylor WJ, Group for Research and Assessment of $\mathrm{PsO}$ and Psoriatic Arthritis (GRAPPA): Treatment recommendations for psoriatic arthritis. Ann Rheum Dis 2009, 68:1387-1394.

37. Mease P: Update on treatment of psoriatic arthritis. Bull NYU Hosp Jt Dis 2012, 70:167-171.

38. Rodgers M, Epstein D, Bojke L, Yang H, Craig D, Fonseca T, Myers L, Bruce I, Chalmers R, Bujkiewicz S, Lai M, Cooper N, Abrams K, Spiegelhalter D, Sutton A, Sculpher M, Woolacott N: Etanercept, infliximab and adalimumab for the treatment of psoriatic arthritis: a systematic review and economic evaluation. Health Technol Assess 2011, 15:i-xxi:1-329.

39. Saad AA, Ashcroft DM, Watson KD, Symmons DP, Noyce PR, Hyrich KL, BSRBR: Efficacy and safety of anti-TNF therapies in psoriatic arthritis: an observational study from the British Society for Rheumatology Biologics Register. Rheumatology (Oxford) 2010, 49:697-705.

40. Kavanaugh A, van der Heijde D, Mclnnes IB, Mease P, Krueger GG, Gladman DD, Gomez-Reino J, Papp K, Baratelle A, Xu W, Mudivarthy S, Mack M, Rahman MU, Xu Z, Zrubek J, Beutler A: Golimumab in psoriatic arthritis: one-year clinical efficacy, radiographic, and safety results from a phase III, randomized, placebo-controlled trial. Arthritis Rheum 2012, 64:2504-2517.

41. Gladman D, Fleischmann R, Coteur G, Woltering F, Mease PJ: Effect of certolizumab pegol on the multiple facets of psoriatic arthritis as reported by patients with and without prior anti-TNF exposure: 24-week patient-reported outcome results of Rapid-PSA study. Ann Rheum Dis 2013, 72(Suppl):s260

42. Chimenti MS, Saraceno R, Chiricozzi A, Giunta A, Chimenti S, Perricone R: Profile of certolizumab and its potential in the treatment of psoriatic arthritis. Drug Des Devel Ther 2013, 7:339-348.

43. Veale DJ: New therapies and new goals for psoriatic arthritis. Arthritis Rheum 2011, 63:874-876.

44. McInnes IB, Sieper J, Braun J, Emery P, van der Heijde D, Isaacs JD, Dahmen G, Wollenhaupt J, Schulze-Koops H, Kogan J, Ma S, Schumacher MM, Bertolino AP, Hueber W, Tak PP: Efficacy and safety of secukinumab, a fully human anti-interleukin-17A monoclonal antibody, in patients with moderate-to-severe psoriatic arthritis: a 24-week, randomised, double-blind, placebo-controlled, phase II proof-of-concept trial. Ann Rheum Dis 2013. [Epub ahead of print].

45. Mclnnes IB, Kavanaugh A, Gottlieb AB, Puig L, Rahman P, Ritchlin C, Brodmerkel C, Li S, Wang Y, Mendelsohn AM, Doyle MK, PSUMMIT 1 Study Group: Efficacy and safety of ustekinumab in patients with active psoriatic arthritis: 1 year results of the phase 3, multicentre, doubleblind, placebo-controlled PSUMMIT 1 trial. Lancet 2013, 382:780-789.

46. Papp KA, Leonardi C, Menter A, Ortonne JP, Krueger JG, Kricorian G, Aras G, Li J, Russell CB, Thompson EH, Baumgartner S: Brodalumab, an anti-interleukin-17-receptor antibody for PsO. N Engl J Med 2012, 366:1181-1189.

47. Leonardi C, Matheson R, Zachariae C, Cameron G, Li L, Edson-Heredia E, Braun D, Banerjee S: Anti-interleukin-17 monoclonal antibody ixekizumab in chronic plaque PsO. N Engl J Med 2012, 366:1190-1199.

48. Saber TP, Ng CT, Renard G, Lynch BM, Pontifex E, Walsh CA, Grier A, Molloy M, Bresnihan B, Fitzgerald O, Fearon U, Veale DJ: Remission in psoriatic arthritis: is it possible and how can it be predicted? Arthritis Res Ther 2010, 12:R94.

49. Kavanaugh A, Mease PJ, Adebajo AO, Wollenhaupt J, Hu C, Shah K, Stevens RM, Gomez-Reino JJ: Long-term (52-week) results of a phase 3, randomized, controlled trial of apremilast, an oral phosphodiesterase 4 inhibitor, in patients with psoriatic arthritis. Ann Rheum Dis 2013, 72(Suppl):s0001.

50. van der Heijde D, Tanaka Y, Fleischmann R, Keystone E, Kremer J, Zerbini C, Cardiel MH, Cohen S, Nash P, Song YW, Tegzova D, Wyman BT, Gruben D, Benda B, Wallenstein G, Krishnaswami S, Zwillich SH, Bradley JD, Connell CA, ORAL Scan Investigators: Tofacitinib (CP-690,550) in patients with rheumatoid arthritis receiving methotrexate: twelve-month data from a twenty-four-month phase III randomized radiographic study. Arthritis Rheum 2013, 65:559-570.

51. Mamolo C, Harness J, Tan H, Menter A: Tofacitinib (CP-690,550), an oral Janus kinase inhibitor, improves patient-reported outcomes in a phase $2 \mathrm{~b}$, randomized, double-blind, placebo-controlled study in patients with moderate-to-severe PsO. J Eur Acad Dermatol Venereol 2013. [Epub ahead of print].

\subsection{6/ar4414}

Cite this article as: Veale: Psoriatic arthritis: recent progress in pathophysiology and drug development. Arthritis Research \& Therapy 2013, 15:224 